\title{
sciendo
}

\section{A Panorama of Digitalization Tendencies in the European Agriculture Sector}

\author{
Cristiana-Ioana ȘERBĂNEL \\ Bucharest University of Economic Studies, Bucharest, Romania \\ cristiana.serbanel@gmail.com
}

\begin{abstract}
Digitalization in the agricultural sector is an imperative upgrade required to confront the predicted food security challenges announced by the United Nations and Food and Agriculture Organization. Smart agriculture goes beyond primary production (crop diseases, crop production), influencing the complete agricultural value chain, including sustainability and the environment. The present paper results were obtained through a well-documented literature review of European smart-farming projects and a quantitative analysis of the actual status of information, communication, and technology practices implemented among the member states. The research questions aimed to assess the European smart-farming projects' distribution among the agricultural value chain and to evaluate digitization's current status at the country-level among member states. At first glance, European Union has implemented over 30 projects with the primary scope to streamline the agricultural sector through massive investments in high-tech technology, autonomous robots, special workshops, and multiple training pieces for farmers and other parties involved along the value chain. The outcomes indicate that the European efforts were mainly orientated towards adding value to the "input-supply" stage. The following immediate focus was to support the entire agricultural supply chain. This article enriches the current literature through a unique combination of the European agricultural value chain and a structured review of the main digitalization projects implemented or which are under-implementation processes among the value chain.
\end{abstract}

Keywords: digitalization, agriculture, value chain, Europe, smart-farming, information, communication and technology.

\section{Introduction}

Digitalization is a driving force that has the power to transform agricultural production, food systems, and the entire agricultural value chain.

Considering the actual context and United Nations (UN) forecasts which predict that the world population is predicted to reach 9 billion by 2050, there is an essential need to optimize the agricultural systems through fast-tracked technological investments. In such a scenario, according to the UN and Food and Agriculture (FAO), farmers ought to produce about $70 \%$ more foodproducts by 2050. This growth will require a transition from labor-intensive to smart agriculture, consisting of high-tech farm equipment, robotics, artificial intelligence, and big data.

Digital transformation is considered "the fourth industrial revolution". It can foster economic and social growth and equally protect the environment. According to McKinsey \& Company (2020), digital technologies can contribute on average by $1.1 \%$ to annual Gross Domestic Product (GDP) in the period 2017-2030. As a result of these technologies, the cumulative effect implies a $14.1 \%$ higher GDP by 2030 in the European Union (EU) 27 states.

This paper aims to evaluate the European agricultural value chain's digitalization situation by analyzing implemented or under implementation smart-farming projects. Moreover, the article pursues to assess how "prepared" are the European Union member states to adopt digitization in the agriculture sector, considering the Information, Communication and Technology Index.

DOI: $10.2478 /$ picbe-2021-0033

(C) 2021 C.-I. Șerbănel, published by Sciendo.

This work is licensed under the Creative Commons Attribution 4.0 License. 


\section{Literature review}

Digitalization is acknowledged as one of the most ubiquitous trends that will fundamentally transform our everyday lives (Yoo, 2010); (Leviäkangas, 2016). Digitalization is perceived as the future in the agriculture industry; digital technologies being the only way to increase business profitability. (Fuchs, 2019) Conversely, Pfeiffer et al., 2021 states that digitalization may also be sensed as a threat by the public.

In brief, digitalization entails the introduction of high-tech technologies into on-going processes. Digitalization brings together the internet of things (IoT), information and communication technologies (ICT), big data, system integration, automated robotics, augmented reality, artificial intelligence, sensors, digital twins, machine learning, and blockchain, among others (Tilson et al., 2010); (Alm et al., 2016); (Smith, 2018); (Leveau et al., 2019), (Chen et al., 2020).

In agriculture, digitalization goes beyond the level of a single entity or business. For instance, several digital platforms are used to connect data and management tasks, enhanced by real-time information, coordinating demand and supply in value chains. (Rose \& Chilvers, 2018); (Wolfert et al., 2014). Several concepts have arisen to express forms of digitalization in agriculture value chains and production systems. These include Smart-Farming (Wolfert et al., 2017); (Blok \& Gremmen, 2018), (Doshi et al., 2019); (Charania \& Li, 2020), Precision-Farming or Precision Agriculture (Wolf \& Buttel, 1996); (Eastwood et al., 2017); (Vecchio et al., 2020); Digital Agriculture (Keogh \& Henry, 2016); (Shepherd et al., 2018); and Farming 4.0 or Agriculture 4.0 (Rose \& Chilvers, 2018); (Klerkx et al., 2019); (Rose et al., 2021). Regardless of the used model, digitalization supports agriculture's value chain actors to precisely interpret the past and predict the future for more accurate decisions through consistent data real-time collecting, monitoring, and interpreting (Janssen et al., 2017); (Wolfert et al., 2017).

The agricultural value chain (VC) is a complex chain that brings together actors and activities to create a farming product from zero-point production to the final consumption. The higher the number of the stage, the higher value is added to the product.

Usually, the terms "value chain" and "supply chain" are used interchangeably. "Value chain" has been used to determine a vertical alliance or strategic network between several independent business organizations within a supply chain (Hobbs et al., 2000).

\section{Methodology}

This paper uses a two-fold approach to identifying key-sources that make available data to address the research questions: how digitalized is currently the European agricultural value chain? Which of the VC's stages received more investments? Are the European member states ready to implement smart-technologies in the agriculture sector? The two elements of the research are: a structured assessment of the leading European smart-farming projects implemented and a subjective assessment of their position on the value chain and a quantitative analysis of the use of Information, Communication, and Technology across the member states.

The first approach used to evaluate the European agriculture digitalization tendencies yielded over 50 papers. Projects' webpages, videos, presentations, objectives, and results were analyzed to define the principal objective and the total cost, where data was available. Figure 1 indicates the flow inside the agricultural value chain from the author's perspective, while Figure 2 comprises the overall European investments in agriculture among the value chain.

The second approach consisted of extracting the latest available data - the year 2018 - from the EUROSTAT database regarding ICT usage at work and other activities related to work. The 
collected data included all the 27 European member states and introduced seven indicators prone to indicate how familiar workers are with digital technologies accurately:

$\mathrm{I}_{1}$ : Individuals used computers, laptops, smartphones, tablets or other portable devices at work;

$\mathrm{I}_{2}$ : Individuals used other computerized equipment or machinery such as those used in production lines, transportation or other services at work;

I3: Individuals used computers, laptops, smartphones, tablets, other portable devices or other computerized equipment or machinery such as those used in production lines, transportation or other services at work;

I4: Individuals exchanged emails or entered data in databases in their work;

I5: Individuals used applications to receive tasks or instructions in their work;

I6: Individuals used occupational specific software in their work;

I7: Individuals developed or maintained IT systems or software in their work.

\section{Results and discussions}

From a general perspective, agricultural commodities are produced by a large number of farmers, and the final products or raw-material (depending on the product itself) are purchased and traded several times between the farm gate and the final consumer. A value chain can be distinguished as a vertical linking or a network between various VC parties involving operations such as harvesting, processing, storing, packaging, transportation, and distribution. (Figure 1) At the end of the valuechain, the final value-added may be influenced by time-delivery, flexibility, quality, innovativeness, costs, and so on. The opportunities of a VC actor to add-value depends on market characteristics and technological capabilities. (FAO, 2005)

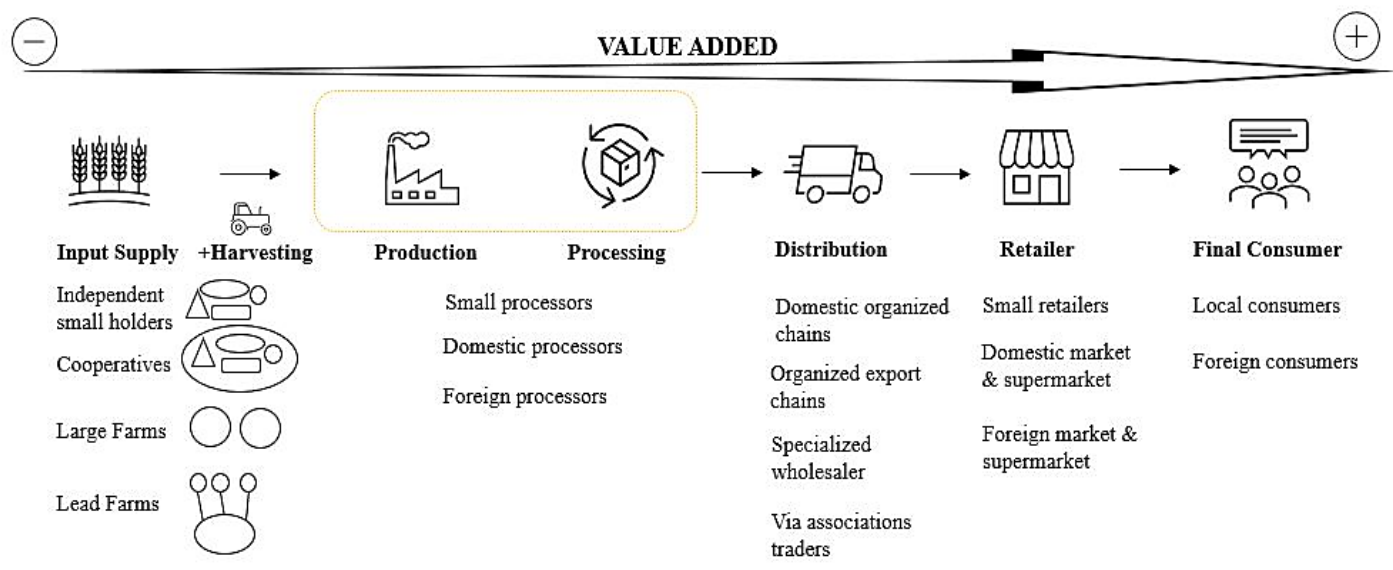

Figure 1. Agricultural Value Chain

Source: Author's own creation inspired by (McCullough et al., 2008) and (Norton, 2014).

To sustain the agricultural innovation projects, the European Union launched several initiatives as the European Rural Development Policy under the CAP, the EU's Horizon 2020 research and innovation programs (H2020), and the Agricultural European Innovation Partnership Program (EIP-AGRI). (FAO \& ITU, 2020). 
Table 1. A structured overview of the leading digital agricultural projects implemented in Europe since 2010

\begin{tabular}{|c|c|c|}
\hline Acronym & Primary Objective and Other Relevant Information & $\begin{array}{l}\text { Value Chain } \\
\text { Position }\end{array}$ \\
\hline 4D4F & $\begin{array}{l}\text { Data-Driven Dairy Decision for Farmers (4D4F) intends to design a network } \\
\text { for dairy farmers, data companies, dairy technology suppliers, veterinarians, } \\
\text { dairy advisors, and researchers to enhance the Decision making on dairy farms } \\
\text { based on data generated by sensors. } \\
\text { 4D4F emphasizes dairy animal and environmental sensors' influence in } \\
\text { collecting real-time data to make more informed dairy farming decisions. } \\
\text { Total cost: } 2 \mathrm{M} €\end{array}$ & $\begin{array}{l}\text { Input Supply } \\
{[1]}\end{array}$ \\
\hline AfriCultuReS & $\begin{array}{l}\text { AfriCultuReS proposes to develop a wide-ranging solution to enhance } \\
\text { decision-making on food security through a decision support system. The } \\
\text { project purposes of delivering agricultural models (crops and livestock), } \\
\text { weather forecast and climate services, in situ data ("crowdsensing"), Earth } \\
\text { Observation for multiple regions in Africa. } \\
\text { Total cost: } 8,5 \mathrm{M} €\end{array}$ & $\begin{array}{l}\text { Input Supply } \\
\text { - main focus. } \\
\text { Production } \\
\text { Processing } \\
\text { [2] }\end{array}$ \\
\hline ATLAS & $\begin{array}{l}\text { ATLAS develops an open digital service platform to create a sustainable } \\
\text { ecosystem for innovative data-driven agriculture. By connecting agricultural } \\
\text { machinery, sensor systems, and data analysis tools, the platform will } \\
\text { sustainably increase farmers' productivity by using the most advanced digital } \\
\text { technology and data. } \\
\text { Total cost: } 15.8 \mathrm{M} €\end{array}$ & $\begin{array}{l}\text { Input Supply } \\
\text { [3] }\end{array}$ \\
\hline CHAMPI-ON & $\begin{array}{l}\text { The Champi-ON project targeted to develop a fully automated system for } \\
\text { picking and handling mushrooms for the fresh market. } \\
\text { Total cost: } 1.09 \mathrm{M} €\end{array}$ & $\begin{array}{l}\text { Input Supply } \\
+ \text { Harvesting } \\
{[4]}\end{array}$ \\
\hline DEMETER & $\begin{array}{l}\text { DEMETER main objectives are to analyze, adapt, improve existing } \\
\text { Information Models in the agri-food sector facilitating data sharing and } \\
\text { interoperability over multiple IoT and Farming Management Information } \\
\text { Systems, including associated technologies; build knowledge; empower the } \\
\text { farmer to gain control in the data-food-chain; establish benchmarking; } \\
\text { supplier relation, demonstrate the impact. } \\
\text { Total cost: } 17.7 \mathrm{M} €\end{array}$ & $\begin{array}{l}\text { Input Supply } \\
\text { - main focus. } \\
\text { Production } \\
\text { Processing } \\
\text { Distribution } \\
\text { Retailer } \\
\text { [5] }\end{array}$ \\
\hline DESIRA & $\begin{array}{l}\text { DESIRA developed the concept of socio-cyber-physical systems to improve } \\
\text { society and political bodies' capacity to react to digitalization challenges in } \\
\text { agriculture, forestry, and rural areas. } \\
\text { Total cost: } 5 \mathrm{M} €\end{array}$ & $\begin{array}{l}\text { Input Supply } \\
{[6]}\end{array}$ \\
\hline ECHORD Plus & $\begin{array}{l}\text { ECHORD Plus proposes to use robotics for precision in agriculture. The } \\
\text { project includes technologies such as cloud computing, image processing, } \\
\text { machine learning, UAV UGV. The robots and new technology are used for } \\
\text { crop monitoring, grafting harvesting, pruning, seeding, spraying, and weed } \\
\text { management. } \\
\text { Total cost: } 26 \mathrm{M} €\end{array}$ & $\begin{array}{l}\text { Input Supply } \\
\text { - main focus; } \\
{[7]}\end{array}$ \\
\hline ECOLUP & $\begin{array}{l}\text { ECOLUP is an integrated logistic solution for the fruit and vegetable sector } \\
\text { that shortens the supply chain, advantageous for both producers and buyers. It } \\
\text { contains an online marketplace for fruit and vegetable products, coordinated } \\
\text { with a network of smart refrigerated lockers fixed with network connectivity } \\
\text { and a deliveries' management software. The project directly connects } \\
\text { producers with buyers and ease the delivery process. } \\
\text { Total cost: } 50.000 €\end{array}$ & $\begin{array}{l}\text { Production } \\
\text { Distribution } \\
\text { Retailer } \\
\text { [8] }\end{array}$ \\
\hline
\end{tabular}

PICBE | 355 


\begin{tabular}{|c|c|c|}
\hline Acronym & Primary Objective and Other Relevant Information & $\begin{array}{l}\text { Value Chain } \\
\text { Position }\end{array}$ \\
\hline EIP AGRI & $\begin{array}{l}\text { The European Innovation Partnership for agricultural productivity and } \\
\text { sustainability (EIP-AGR) concentrates on establishing partnerships and } \\
\text { linking people from diverse professional backgrounds through various } \\
\text { actions. The project brings together farmers, advisers, researchers, } \\
\text { agribusinesses, NGOs, and other stakeholders. }\end{array}$ & $\begin{array}{l}\text { Input Supply } \\
\text { - main focus. } \\
\text { Production } \\
\text { Processing } \\
\text { Distribution } \\
\text { Retailer } \\
\text { [9] }\end{array}$ \\
\hline ENORASIS & $\begin{array}{l}\text { ENORASIS aimed to develop an intelligent and integrated decision support } \\
\text { system for environmentally optimized and sustainable irrigation } \\
\text { administration for farmers and water management standards. } \\
\text { Total cost: } 2.7 \mathrm{M} €\end{array}$ & $\begin{array}{l}\text { Input Supply } \\
{[10]}\end{array}$ \\
\hline ERMES & $\begin{array}{l}\text { ERMES produced a prototype of downstream services centered on integrating } \\
\text { EO and in situ data from crop modeling solutions. } \\
\text { Crop: rice. }\end{array}$ & $\begin{array}{l}\text { Input Supply } \\
\text { [11] }\end{array}$ \\
\hline FAIRshare & $\begin{array}{l}\text { FAIRshare plans to mobilize the rural advisory community to use analytics } \\
\text { and communication technologies for agricultural sustainability through } \\
\text { digitalization. The initiatives engage a multi-actor approach and involve all } \\
\text { actors' participation, from independent farm advisors to farmer clients. } \\
\text { Total cost: } 7 \mathrm{M} €\end{array}$ & $\begin{array}{l}\text { Input Supply } \\
\text { and Final } \\
\text { Consumer } \\
{[12]}\end{array}$ \\
\hline FIGARO & $\begin{array}{l}\text { FIGARO is a platform created to make available flexibility and precision in } \\
\text { irrigation to improve farm-scale and water productivity. }\end{array}$ & $\begin{array}{l}\text { Input Supply } \\
{[13]}\end{array}$ \\
\hline Flourish & $\begin{array}{l}\text { Flourish aims to introduce precision farming through robots that will collect } \\
\text { data about the soil, crops, pests, water levels, and extra factors. The adequate } \\
\text { interpretation of the collected data will increase a farm's yield while } \\
\text { minimizing the use of chemicals. } \\
\text { Total cost: } 4.8 \mathrm{M} €\end{array}$ & $\begin{array}{l}\text { Input Supply } \\
\text { [14] }\end{array}$ \\
\hline FIT4FOOD2030 & $\begin{array}{l}\text { The FOOD } 2030 \text { Platform was designed to mobilize several stakeholders via } \\
\text { an interlinked arrangement at the cities, regions, countries, and European } \\
\text { level. The platform's main objectives are to consolidate R\&I policy coherence } \\
\text { and alignment, build competencies, and increase awareness of the FOOD } 2030 \\
\text { policy structure. } \\
\text { Total cost: } 3.9 \mathrm{M} €\end{array}$ & $\begin{array}{l}\text { Value Chain } \\
{[15]}\end{array}$ \\
\hline FOODIE & $\begin{array}{l}\text { Farm Orientated Open Data in Europe Project object was to improve farm } \\
\text { management processes by providing support with: (1) Earth observation } \\
\text { techniques, (2) crop and agricultural land use monitoring methods, (3) model } \\
\text { development, and (4) spatial and statistical analysis. }\end{array}$ & $\begin{array}{l}\text { Mainly Input } \\
\text { Supply and } \\
\text { Distribution } \\
{[16]}\end{array}$ \\
\hline FRACTALS & $\begin{array}{l}\text { The FRACTALS project represents one of the } 16 \text { accelerators within the } \\
\text { FIWARE community throughout Europe, supporting FIWARE based } \\
\text { applications for the agricultural sector. FRACTALS launched a challenge for } \\
\text { small and medium enterprises, web-entrepreneurs, and startups ready to use } \\
\text { FIWARE technologies to provide innovative solutions for urban farming } \\
\text { challenges. }\end{array}$ & $\begin{array}{l}\text { Input Supply } \\
\text { [17] }\end{array}$ \\
\hline GATES & $\begin{array}{l}\text { GATES's goal is to develop a game-based training platform to qualify } \\
\text { professionals across the agricultural value chain using smart-farming } \\
\text { technologies. } \\
\text { Total cost: } 1.2 \mathrm{M} €\end{array}$ & $\begin{array}{l}\text { Value Chain } \\
{[18]}\end{array}$ \\
\hline
\end{tabular}

DOI: 10.2478/picbe-2021-0033, pp. 352-363, ISSN 2558-9652 |

Proceedings of the $15^{\text {th }}$ International Conference on Business Excellence 2021 


\begin{tabular}{|c|c|c|}
\hline Acronym & Primary Objective and Other Relevant Information & $\begin{array}{l}\text { Value Chain } \\
\text { Position }\end{array}$ \\
\hline IoF2020 & $\begin{array}{l}\text { The IoF2020 project intends to speed up the IoT's adoption to safeguard } \\
\text { sufficient, safe, and healthy food and improve the competitiveness of farming } \\
\text { and food chains in Europe. The project brings together farmers, the food } \\
\text { industry, technology providers, and research institutes. } \\
\text { Total cost: } 35 \mathrm{M} €\end{array}$ & $\begin{array}{l}\text { Mostly Input } \\
\text { Supply } \\
{[19]}\end{array}$ \\
\hline MISTRALE & $\begin{array}{l}\text { The Mistrale project proposes providing soil moisture maps using GNSS } \\
\text { Reflectometry, for decision-makers in water management, like farmers, nature } \\
\text { management, and water boards. }\end{array}$ & $\begin{array}{l}\text { Input Supply } \\
{[20]}\end{array}$ \\
\hline NIVA & $\begin{array}{l}\text { New IACS Vision in Action (NIVA) delivers a set of digital solutions, e-tools, } \\
\text { and good practices for initiates and e-governance, an innovation ecosystem to } \\
\text { sustain further development of Integrated Administration and Control System } \\
\text { (IACS ) that will simplify data and information flows. IACS harmonizes data } \\
\text { sets to monitor agricultural performance while lowering farmers' } \\
\text { administrative burden, paying organizations, and other stakeholders. } \\
\text { Total cost: } 5 \mathrm{M€}\end{array}$ & $\begin{array}{l}\text { Value Chain } \\
\text { with focus on } \\
\text { Input Supply } \\
\text { [21] }\end{array}$ \\
\hline PANTHEON & $\begin{array}{l}\text { PANTHEON elaborates the agricultural equivalent of an industrial } \\
\text { Supervisory Control and Data Acquisition system. The technology will } \\
\text { provide precision farming in large hazelnut orchards. } \\
\text { Total cost: } 3,1 \mathrm{M} €\end{array}$ & $\begin{array}{l}\text { Input-Supply } \\
{[22]}\end{array}$ \\
\hline PhytlSigns & $\begin{array}{l}\text { PhytlSigns is a pioneering technology system that provides early warnings of } \\
\text { a wide range of crop stressors, enabling producers to increase yields and } \\
\text { choose environmentally preferable crop protection. PhytlSigns helps growers } \\
\text { to make more informed and cost-effective choices through the early discovery } \\
\text { of crop threats, speed up product development cycles and testing, deliver new } \\
\text { insights for researchers. } \\
\text { Total cost: } 50.000 €\end{array}$ & $\begin{array}{l}\text { Input Supply } \\
{[23]}\end{array}$ \\
\hline ROMI & $\begin{array}{l}\text { ROMI aims to promote sustainable, local, and human-scale agriculture. ROMI } \\
\text { involves the development of a multipurpose platform to sustain organic and } \\
\text { polyculture market-garden farms. The equipment used comprises of robotic } \\
\text { tools, data, shared documentation, and research, and it will optimize } \\
\text { production and enhance farmers' working conditions. It covers crop } \\
\text { monitoring and weed management. } \\
\text { Total cost: } 3.9 \mathrm{M} €\end{array}$ & $\begin{array}{l}\text { Input Supply } \\
{[24]}\end{array}$ \\
\hline $\begin{array}{l}\text { S3 HIGH TECH } \\
\text { FARMING }\end{array}$ & $\begin{array}{l}\text { The project aims to implement advanced agri-technologies in small and family } \\
\text { farms and involve various business sectors. Technologies used: Robotics, } \\
\text { ICT, Big Data, Earth Observation. }\end{array}$ & $\begin{array}{l}\text { Input Supply } \\
{[25]}\end{array}$ \\
\hline S3P Agri-Food & $\begin{array}{l}\text { The platform will accelerate innovation and promote regional economic } \\
\text { transformation by generating new value chains and connecting business } \\
\text { organizations, clusters, research institutions, academia, and civil society. } \\
\text { The project will add value to the following axes: (1) Consumer Involvement } \\
\text { in Agri-food Innovation, (2) High-Tech Farming, (3) Nutritional Ingredients, } \\
\text { (4) Smart sensor systems four agri-food, and (5) Traceability \& Big Data. }\end{array}$ & $\begin{array}{l}\text { Value chain } \\
{[26]}\end{array}$ \\
\hline $\begin{array}{l}\text { Smart sensors } 4 \\
\text { agri-food }\end{array}$ & $\begin{array}{l}\text { The project's objective is to support agri-food companies in leaping towards } \\
\text { digitalization and ensuring that the agri-food sector develops into an } \\
\text { interconnected, resilient, and intelligent environment. The initiative brings } \\
\text { together clusters, technology \& digital solutions providers, stakeholders, and } \\
\text { companies, including small-farmers. }\end{array}$ & $\begin{array}{l}\text { Value Chain } \\
\text { [27] }\end{array}$ \\
\hline
\end{tabular}

DOI: 10.2478/picbe-2021-0033, pp. 352-363, ISSN 2558-9652 |

Proceedings of the $15^{\text {th }}$ International Conference on Business Excellence 2021 


\begin{tabular}{|c|c|c|}
\hline Acronym & Primary Objective and Other Relevant Information & $\begin{array}{l}\text { Value Chain } \\
\text { Position }\end{array}$ \\
\hline SmartAgriHubs & $\begin{array}{l}\text { SmartAgriHubs aims to accelerate the digital transformation of the European } \\
\text { agri-food sector. The project brings together a consortium of well over } 164 \\
\text { partners in the European agri-food sector, out of which } 140 \text { are Digital } \\
\text { Innovation Hubs embedded within } 9 \text { Regional Clusters. } \\
\text { Total cost: } 20 \mathrm{M} €\end{array}$ & $\begin{array}{l}\text { Value Chain } \\
{[28]}\end{array}$ \\
\hline SMART-AKIS & $\begin{array}{l}\text { SMART-AKIS creates and spreads practical solutions to farmers directly from } \\
\text { the research results, adding already implemented European projects in Smart } \\
\text { Farming to stimulate the cooperation between the farming community, } \\
\text { research and Smart Farming technology providers, and the extension and } \\
\text { advisory services with the final scope to generate innovative solutions in } 4.0 \\
\text { farming. }\end{array}$ & $\begin{array}{l}\text { Value Chain } \\
\text { [29] }\end{array}$ \\
\hline $\begin{array}{l}\text { Smart Anything } \\
\text { Everywhere } \\
(\text { SAE) }\end{array}$ & $\begin{array}{l}\text { SAE's objective is to assure that any industry in Europe can fully take } \\
\text { advantage of digital innovations to upgrade products, enhance processes and } \\
\text { redesign business models to the digital age. It covers the following areas: } \\
\text { environment, transport, agriculture, digitized anything, automotive, health, } \\
\text { construction. There are nine agricultural sector projects. } \\
\text { Total Cost: } 3.9 \mathrm{M} € \text { (for all sectors) }\end{array}$ & $\begin{array}{l}\text { Value Chain } \\
{[30]}\end{array}$ \\
\hline SMART COW & $\begin{array}{l}\text { Smart Cow combines enhanced use of existing research infrastructures and } \\
\text { stimulates collaboration across research fields, production systems, and } \\
\text { national borders. The project includes thematic such as feed resources that } \\
\text { promote animal welfare and healthy livestock, innovative and ethical solutions } \\
\text { for efficient animal welfare, and sustainable competitiveness. } \\
\text { Total Cost: } 5 \mathrm{M} €\end{array}$ & $\begin{array}{l}\text { Input Supply } \\
\text { - focus and } \\
\text { value chain } \\
{[31]}\end{array}$ \\
\hline SWEEPER & $\begin{array}{l}\text { Sweeper's primary objective was to make available the first-generation } \\
\text { greenhouse harvesting robots into the market. The project would ensure } \\
\text { Europe's leading role in agricultural robotics. } \\
\text { Total cost: } 4.3 \mathrm{M} €\end{array}$ & $\begin{array}{l}\text { Input Supply } \\
\text { [32] }\end{array}$ \\
\hline $\begin{array}{l}\text { S3 Traceability } \\
\text { \& Big Data }\end{array}$ & $\begin{array}{l}\text { 3P Agri-food Thematic Partnership on Traceability and Big Data in the agri- } \\
\text { food value chain seeks to facilitate the agri-food value chain's digitalization } \\
\text { process by adopting smart technologies and the value creation from data. }\end{array}$ & $\begin{array}{l}\text { Value Chain } \\
\text { [33] }\end{array}$ \\
\hline VINBOT & $\begin{array}{l}\text { VINBOT digitalizes vineyards through autonomous mobile robots that are } \\
\text { qualified to capture and analyze vineyard images and 3D data to ascertain the } \\
\text { yield of vineyards and distribute it to the winegrowers. Activities: monitoring } \\
\text { yield, prediction. } \\
\text { Total cost: } 2 \mathrm{M} €\end{array}$ & $\begin{array}{l}\text { Input - Supply } \\
\text { [34] }\end{array}$ \\
\hline
\end{tabular}

Source: Author's data compilation (2021).

General Note: For most of the projects, the cost was totally or $80 \%-90 \%$ supported by the EU. Although the projects attempted to involve most of the EU's member states, countries like Italy, Spain, Greece, and the Netherlands have been predominantly involved either through research clusters, universities, or farmers. When the project did not explicitly define its implementation area and touched different VC implementation-segments, it was considered to cover the entire value chain. Most of the projects started six years ago (2015), and some of the projects were successfully closed; others are still running. For further research, Bacco et al. (2019) present a general overview of each European project's most relevant technologies.

As Table 1 signifies, the EU's objective is to revitalize and sustain the agriculture industry through a wide-spread digitalization inclusively for small farmers by funding research programs to support innovative food products, rural development, and bioeconomy. The EU proposal for the multiannual financial framework (MFF) for the 2021-2027 period includes EUR 365 billion for CAP - representing 28.5\% of the EU budget (European Commission, 2018). An additional EUR 
192 million was granted under Horizon 2020 Societal Challenge 2 SC2, involving 434 participants. (European Commission, 2019).

The EU's focus was essentially orientated towards the first stage of the value chain, increasing efficiency and precision in farming activities (e.g., water-management, cropmonitoring, fertilization, disease-identification). Figure 2 comprises a visual overview of the digitalization projects implemented across the agricultural value chain.

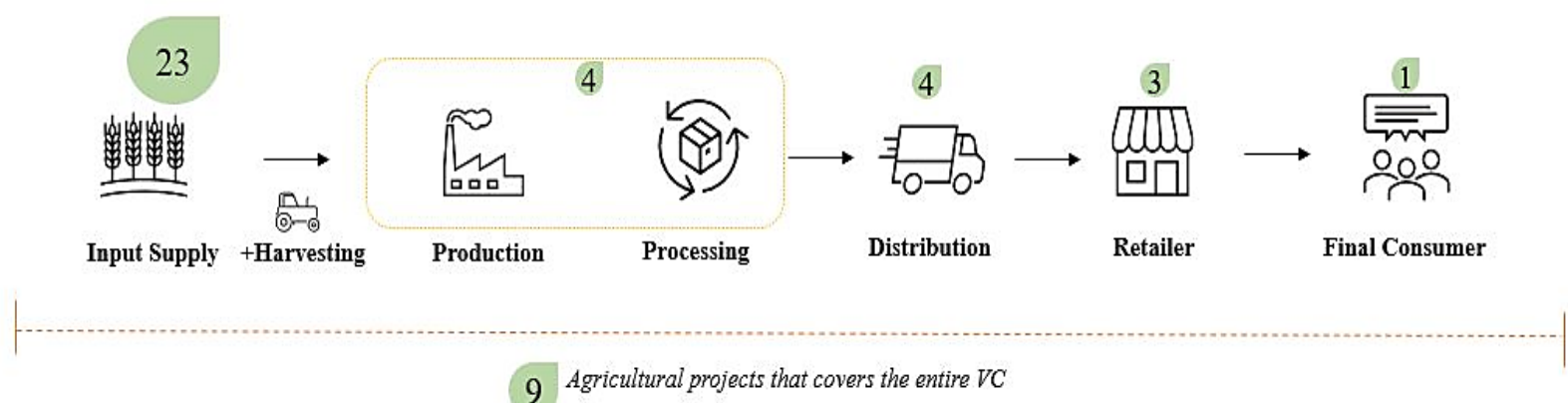

Figure 2. European digital projects distribution among the agricultural value chain

Source: Author's own creation based on research (2021).

Agricultural digitalization was orientated mainly towards the value chain's first step - Input Supply. It is a notable observation since the input-supply can influence all the other sequential stages of the value chain. Almost half of the projects dedicated to the first stage contributed with a scattered value and covered the entire value chain. Other phases of the agricultural value chain which received funding and attention were "Production \& Processing", "Distribution", "Retailer," and "Final Consumer."

The agriculture sector's digitalization constrains a previously grounded ICT framework and implicitly trained human-capital. Otherwise, the process will take longer, and it will require higher investments. At first glance, it can be remarked that the use of ICT at work is divided into two main categories: countries that have already made impressive advancements (Netherlands, Germany, Finland, Estonia, Austria, Malta, Sweden, Luxemburg) and countries that are still far behind the former group (Romania, Bulgaria, Greece, Croatia, Hungary, Slovakia) (Figure 3).

As far as it concerns the third selected indicator "Individuals used computers, laptops, smartphones, tablets, other portable devices or other computerized equipment or machinery such as those used in production lines, transportation or other services at work", the top-performing countries are Netherlands (61\%), Germany (54\%) and Denmark (52\%). At the opposite pole, the lowest percentage was registered in Romania (18\%), Bulgaria (21\%), and Greece (24\%). 


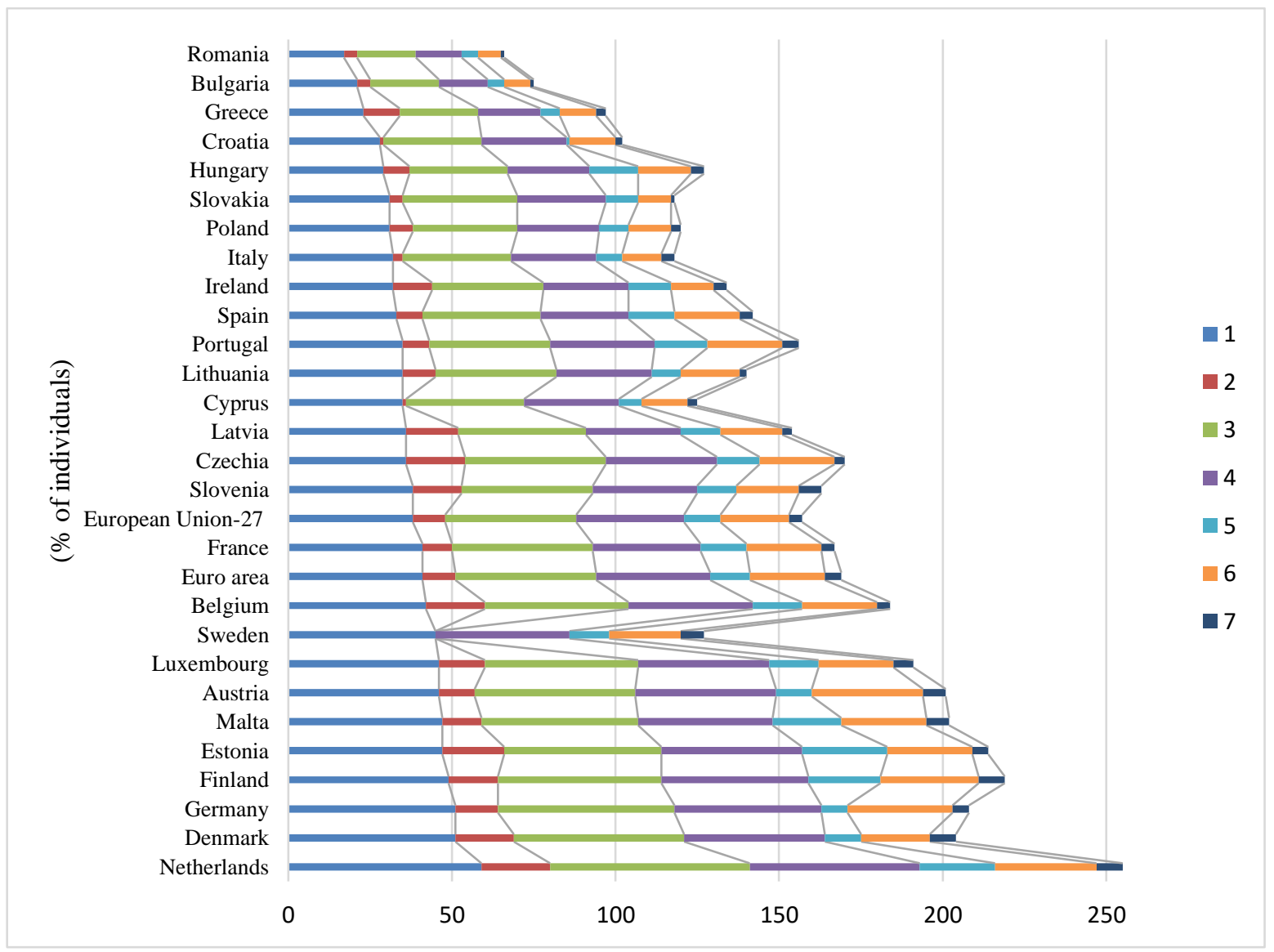

Figure 3. Use of ICT at work and activities performed in Europe (2018, \% of individuals)

Source: Author's extraction from EUROSTAT (2021).

Note: For Sweden, the data is missing for [2] and [3].

Legend:

1: Individuals used computers, laptops, smartphones, tablets or other portable devices at work

2: Individuals used other computerized equipment or machinery such as those used in production lines, transportation or other services at work

3: Individuals used computers, laptops, smartphones, tablets, other portable devices or other computerized equipment or machinery such as those used in production lines, transportation or other services at work

4: Individuals exchanged emails or entered data in databases in their work

5: Individuals used applications to receive tasks or instructions in their work

6: Individuals used occupational specific software in their work

7: Individuals developed or maintained IT systems or software in their work

Notably, the fifth indicator, "Individuals used applications to receive tasks or instructions in their work," indicates a downgrade in Germany (8\%) and Denmark (11\%) performance. As far as it concerns "Individuals used occupational specific software in their work", Austria (34\%), Germany (32\%), Netherlands (31\%) are the top performers, while Romania (7\%), Bulgaria (8\%), Slovakia (10\%) are at the opposite pole.

Finally, the largest share of "Individuals developed or maintained IT systems or software in their work" is registered by Denmark and Netherlands (8\%), Austria, Malta, Slovenia, Sweden (7\%). Conversely, only $1 \%$ of the individuals developed or maintained IT systems or software in their work in Romania, Bulgaria, and Slovakia. 
A fragmented usage of ICT at work and activities leads to slowdowns and hindrances in digitizing the European agriculture sector. More into depth, there is an indirect correlation in terms of ICT performance and the share of agricultural land by country. Among the European nations with the highest agricultural land available are France, Spain, Germany, Poland, and Romania. At the same time, most of these countries are among the lowest performers in using ICT at work and other activities. Admittedly, implementing and spreading digitization measures among all the member-states with high agricultural potential will move-up Europe on the global agricultural value chain.

\section{Conclusion}

This article has provided a summary of the digitalization projects in the European agriculture sector. Being an investigative analysis, beyond summarizing each of the identified project's main objectives, the author grouped the projects under six main-stages of the agricultural value chain: input-supply, production \& processing, distribution, retailer, final consumer, and the entire value chain.

It was found the European focus was orientated mainly towards the input-supply stage with 23 projects. The number of projects that influenced the entire value chain was 9 , while for the other stages there were identified, the following number of initiatives: production \& processing (4), distribution (4), retailer (3), final consumer (1). Furthermore, the paper adds a general perspective of the ICT use at work among other EU member states' activities.

When reflecting on the paper findings, limitations should be considered. Most importantly, the review of the current digitalization agricultural projects and their equivalent to the six stages of the value chain was ultimately the result of the author's interpretation and judgment. This limitation was minimized by consulting several scientific sources concerning the agricultural value chain stages and by studying a broader set of references for the selected project to understand better which stage it addresses.

To move-up on the agricultural VC and to enhance the sector's competitiveness, there is an imperative need to combine cooperation, interconnection, and interchange of skills and knowledge. Moreover, small producers should be supported to increase efficiency through access to smarttechnologies and expertise. The sooner is intervened in the agricultural chain, the more evenly the value is distributed to each VC member, including the final customer who receives access to better products whether in terms of price, quality, or availability. Further, a more homogenized implementation of ICT at work is required, and the countries with less performance should receive special attention from the European Union to close the ICT gap promptly.

\section{Acknowledgement}

The present study is part of the post-doctoral project "Analysis of the competitive sectorial position in the global business network. Romania and the agricultural sector" coordinated by the postdoctoral School of Economics and International Affairs.

\section{References}

Alm, E., Colliander, Lind, F., Stohne, V., Sundström, O., Wilms, M., \& Smits, M. (2016). Digitizing the Netherlands: How the Netherlands Can Drive and Benefit From an Accelerated Digitized Economy in Europe. Boston Consulting Group. 
Bacco, M., Barsocchi, P., Ferro, E., Gotta, A., \& Ruggeri, M. (2019). The Digitisation of Agriculture: a Survey of Research Activities on Smart Farming. Array, 3-4.

Blok, V., \& Gremmen, B. (2018). Agricultural Technologies as Living Machines: Toward a Biomimetic Conceptualization of Smart Farming Technologies. Ethics, Policy \& Environment, 21, 246-263.

Charania, I., \& Li, X. (2020). Smart farming: Agriculture's shift from a labor intensive to technology native industry. Internet of Things, 9.

Chen, Y., Li, Y., \& Li, C. (2020, September 20). Electronic agriculture, blockchain and digital agricultural democratization: Origin, theory and application. Journal of Cleaner Production, 268.

Doshi, J., Patel, T., \& Bharti, S. K. (2019). Smart Farming using IoT, a solution for optimally monitoring farming conditions. Procedia Computer Science, 745-751.

Eastwood, C., Klerkx, L., \& Nettle, R. (2017). Dynamics and distribution of public and private research and extension roles for technological innovation and diffusion: case studies of the implementation and adaptation of precision farming technologies. Journal of Rural Studies, $1-12$.

European Commission. (2018, June 1). EU Budget: the Common Agricultural Policy beyond 2020. Retrieved February 10, 2021, from https://ec.europa.eu/commission/presscorner/detail/en/ MEMO_18_3974.

European Commission. (2018, August 2). The common agricultural policy at a glance. Retrieved February 3, 2021, from https://ec.europa.eu/info/food-farming-fisheries/key-policies/ common-agricultural-policy/cap-glance_en.

European Commission. (2019). Digital Transformation in Agriculture and Rural Areas. European Commission. Retrieved February 14 2021, from https://ec.europa.eu/info/sites/info/files/ food-farming-fisheries/farming/documents/factsheet-agri-digital-transformation_en.pdf.

FAO \& ITU. (2020). Status of Digital Agriculture in 18 countries of Europe and central Asia. Geneva, Switzerland: ITU and FAO.

FAO. (2005). Addressing marketing and processing constrains that inhibit agrifood exports. Rome: Food and Agriculture Organization of the United Nations.

Fuchs, A. (2019). The digitalization of farming means improving the processes. ATZ Heavy Duty worldw, 22-25. doi:https://doi-org.am.e-nformation.ro/10.1007/s41321-019-0058-y.

Hobbs, J., Cooney, A., \& Fulton, M. (2000). Value chains in the agri-food. Department of Agricultural Economics.

Janssen, S. J., Porter, C. H., Moore, A. D., Athanasiadis, I. N., Foster, I., Jones, J. W., ... John, M. (2017, July). Towards a new generation of agricultural system data, models and knowledge products: Information and communication technology. Agricultural Systems, 155, 200-212.

Keogh, M., \& Henry, M. (2016). The Implications of Digital Agriculture and Big Data for Australian Agriculture. Sydney, Australia: Australian Farm Institute.

Klerkx, L., Jakku, E., \& Labarthe, P. (2019, December). A review of social science on digital agriculture, smart farming and agriculture 4.0: New contributions and a future research agenda. NJAS - Wageningen Journal of Life Sciences, 90-91.

Leveau, L., Bénel, A., Cahier, J.-P., \& Pinet, F. (2019). Information and Communication Technology (ICT) and the Agroecological Transition. In J.-E. Bergez, E. Audouin, \& O. Therond, Agroecological Transitions: From Theory to Practice in Local Participatory Design, 263-287, Colmar, France: Springer. 
Leviäkangas, P. (2016). Digitalisation of Finland's transport sector. Technology in Society, 1-15. doi:https://doi.org/10.1016/j.techsoc.2016.07.001.

McCullough, E. B., Pingali, P. L., \& G. Stamoulis, K. (2008). The Transformation of Agri-Food Systems. Globalization, Supply Chains and Smallholder Farmers. London: The Food and Agriculture Organization of the United Nations and Earthscan.

McKinsey \& Company. (2020). Shaping the digital transformation in Europe. European Commission. Retrieved January 30, 2021, from file:///C:/Users/crist/OneDrive/Desktop/ Economicpotentialsummarypaperpdf.pdf.

Norton, R. (2014, July 28). Agricultural value chains: A game changer for small holders. Retrieved February 1, 2021, from Devex: https://www.devex.com/news/agricultural-value-chains-agame-changer-for-small-holders-83981.

Pfeiffer, J., Gabriel, A., \& Gandorfer, M. (2021). Understanding the public attitudinal acceptance of digital farming technologies: a nationwide survey in Germany, Agric Hum Values, 38, 107-128.

Rose, C. D., Rebecca, W., Winter, M., Lobley, M., \& Chivers, C.-A. (2021). Agriculture 4.0: Making it work for people, production, and the planet, Land Use Policy.

Rose, D. C., \& Chilvers, J. (2018). Agriculture 4.0: Broadening Responsible Innovation in an Era of Smart, Frontiers in Sustainable Food Systems, 2(87).

Shepherd, M., Turner, J., Small, B., \& Wheeler, D. (2018). Priorities for science to overcome hurdles thwarting the full promise of the 'digital agriculture' revolution, Science of Food and Agriculture.

Smith, M. J. (2018, November 21). Getting value from artificial intelligence in agriculture. Animal Production Science, 60(1), 46-54, doi:https://doi.org/10.1071/AN18522.

Tilson, D., Lyytinen, K., \& Sørensen, C. (2010, November 18). Research Commentary - Digital Infrastructures: The Missing IS Research Agenda, Information and Systems Research, 748-759.

Vecchio, Y., De Rosa, M., Adinolfi, F., Bartoli, L., \& Masi, M. (2020). Adoption of precision farming tools: A context-related analysis, Land Use Policy.

Wolf, S. A., \& Buttel, F.H. (1996). The Political Economy of Precision Farming, American Journal of Agricultural Economics, 1269-1274.

Wolfert, J., Ge, L., Verdouw, C., \& Bogaardt, M.-J. (2017, May). Big Data in Smart Farming - A review, Agricultural Systems, 153, 69-80.

Wolfert, S., Goense, D., \& Sørensen, C.A. (2014). A future internet collaboration platform for safe and healthy food from farm to fork, Paper presented at the 2014 Annual SRII Global Conference.

Yoo, Y. (2010). Computing in Everyday Life: A Call for Research on Experiential Computing. MIS Quarterly, 213-231. 